\title{
Career Commitment, Subjective Career Success and Career Satisfaction in the Context of Hazelnut Processing Industry in Giresun/Turkey
}

\author{
Gulsah Karavardar ${ }^{1}$ \\ ${ }^{1}$ Giresun University, Turkey \\ Correspondence: Gulsah Karavardar, Giresun University, Turkey. E-mail: gkaravardar@yahoo.com
}

Received: December 19, 2013

Accepted: April 1, 2014

Online Published: May 22, 2014

doi:10.5539/ijbm.v9n6p98

URL: http://dx.doi.org/10.5539/ijbm.v9n6p98

\begin{abstract}
This study aims to study the effect of career commitment on subjective career success with the mediating role of career satisfaction in the context of hazelnut processing industry in Giresun/Turkey. Giresun is one of the cities that placed in the Blacksea Region of Turkey. Giresun's hazelnut quality is the highest quality hazelnut in the world (Hazelnut Promotion Group (HPG), 2013). Therefore, hazelnut processing industry is vital for Giresun's economy. This study was conducted on employees who work in hazelnut processing industry in Giresun, Turkey. This study's results make a valuable contribution to both career commitment and subjective career success literatures by presenting findings of the mediating effect of career satisfaction on the relationship between career commitment and subjective career success in the context of hazelnut processing industry in Giresun. It argues that the effects of career commitment on subjective career success can be mediated by career satisfaction in this context.
\end{abstract}

Keywords: career commitment, career satisfaction, subjective career success, hazelnut processing industry, Turkey

\section{Introduction}

The term "career" is more broadly applied and is commonly considered to be the lifelong sequence of role-related experiences of individuals (Hall, 2002). In general, career commitment involves the development of personal career goals and an identification with and involvement in those goals (Collarelli \& Bishop, 1990). Career success is defined as the accumulated positive work and psychological outcomes arising from one's work experiences (Seibert \& Kraimer, 2001). Subjective career success refers to individuals' evaluation of their career progress, accomplishments and anticipated outcomes, relative to their own goals and aspirations (Seibert, Kraimer, \& Crant, 2001). Jen-Ruei Fu (2010) defined career satisfaction as the level of overall happiness experienced through one's choice of career. This study aims to study the effect of career commitment on subjective career success with the mediating effect of career satisfaction. In the literature, only one study has been done to search the relationships between those three variables (Srikanth \& Israel, 2012).

Hazelnuts that grown in Turkey are two types: Giresun quality and Levant quality. Giresun quality hazelnuts are mainly grown in Giresun and some districts in Trabzon. These are the highest quality hazelnuts in the world (HPG). Besides, hazelnut processing industry is the most important industry in Giresun. Hence, this study's results make a valuable contribution to both career commitment and subjective career success literatures by presenting findings of the mediating effect of career satisfaction on the relationship between career commitment and subjective career success in the context of hazelnut processing industry in Giresun/Turkey. This study argues that the effects of career commitment on subjective career success can be mediated by career satisfaction in this context. Participants who have high career satisfaction would increase their commitment to attain subjective career success as opposed to those who have less career satisfaction and less committed.

\section{Literature Review}

\subsection{Career Commitment}

"Career" is more broadly applied and is commonly considered to be the lifelong sequence of role-related experiences of individuals (Hall, 2002). Researches have defined 'career' term from different point of view in 
the literature. Greenhaus (1987) described a career as a series of jobs held during an individual's lifetime. Hall (1976) described a career as an identification with and involvement in one's profession. Career commitment is defined as "the strength of one's motivation to work in a chosen career role" (Hall, 1971). Blau (1988) described a career commitment as 'one's attitude towards one's profession or vocation'. Career commitment involves the development of personal career goals and an identification with and involvement in those goals (Collarelli \& Bishop, 1990). Career commitment refers to identification with and involvement in one's occupation (Mueller, Wallace, \& Price, 1992). Carson and Bedeian (1994) defined career commitment as "one's motivation to work in a chosen vocation". To sum up, career commitment involves the development of personal career goals and an identification with and involvement in those goals (Collarelli \& Bishop, 1990).

Career commitment is characterized by the development of personal career goals and the individual's attachment to, identification with and involvement in those goals (Colarelli \& Bishop, 1990). Individuals being unable to depend on a single organization to sustain an entire career (Bremner, Robello, Schiller, \& Weber, 1991; Nussbaum, 1991). Career commitment involves self-generated goals and commitment to one's own career, which may lead to employment in several organizations (Randall, 1987). Work environments and the pace of careers in organizations have led employees to exhibit more commitment to their careers and perhaps less or conditional commitment to their organizations (Noordin, Williams, \& Zimmer, 2002). Career commitment has become a significant source of occupational meaning and continuity as organizations become flatter and less able to provide secure jobs or careers (Colarelli \& Bishop, 1990; Aryee, Yue, \& Chew, 1994).

\subsection{Subjective Career Success}

Arthur, Hall, and Lawrence (1989) have defined a career as an "evolving sequence of a person's work experiences over time." A broad definition of career success commonly referred to in the contemporary literature is "the experience of achieving goals that are personally meaningful to the individual, rather than those set by parents, peers, an organization, or society" (Mirvis \& Hall, 1994). The accumulation of achievements (real or subjective) arising from these work experiences is career success (Judge, Cable, Boudreau, \& Bretz, 1995). "career success" can be defined as the "positive psychological and work-related outcomes accumulated as a result of one's work experiences" (Seibert \& Kraimer, 2001). Career success is highlighted as having both objective and subjective components (Gattikerand \& Larwood, 1988; Baruch 2004; Breland, Treadway, Duke, \& Adams, 2007). Objective career success is defined by reference to societal or cultural factors and includes lateral (increased job security, longer vacations) or hierarchical (promotion, different job title) factors (Nabi, 1999).

The traditional career model defines success in terms of observable, socially recognized indicators (e.g., income and advancement) and posits that subjective career success results from achieving objective career success (Judge et al., 1995). Gattiker and Larwood (1986) asserted that unlike objective success criteria, subjective measures may detect important career outcomes that are not readily assessable from personnel records or by expert raters. They also indicated that subjective career success is more of an internal perspective that refers to an individual's own disposition for development in a chosen occupation or profession. According to Hall and Chandler (2005) and Hall and Mirvis (1995), because of the change in career context, individuals aren't expected to rely on their organization's directions for career improvement. They are expected to self-manage their own careers. Subjective career success refers to individuals' evaluation of their career progress, accomplishments and anticipated outcomes, relative to their own goals and aspirations (Seibert \& Kraimer, 2001). Subjective career success reflects an individual's perception of his or her career experiences (Gattiker \& Larwood, 1986). It is one's feelings of accomplishment and satisfaction with one's career (Judge et al., 1995).

\subsection{Career Satisfaction}

Career satisfaction is the satisfaction that individuals derive from the intrinsic and extrinsic aspects of their careers, including pay, advancement, and developmental opportunities (Greenhaus, Parasuraman, \& Wormley, 1990). Jen-Ruei $\mathrm{Fu}$ (2010) defined career satisfaction as the level of overall happiness experienced through one's choice of career.

Employees' career satisfaction reflects how they feel about their career-related roles, accomplishments and success. Significant predictors of career satisfaction include goal-specific environmental support and resources which provide social and material support for an employee's personal goals (Barnett \& Bradley, 2007). Career satisfaction measures the extent to which individuals believe their career progress is consistent with their own goals, values and preferences (Erdogan, Kraimer, \& Liden, 2004; Heslin, 2003; Seibert \& Kraimer, 2001).

\subsection{The Relations among Career Commitment, Career Satisfaction, and Subjective Career Success}

In the literature, there is only one study that conducted with these variables. Besides, there is not any study 
which is conducted in the hazelnut processing industry. However, an association between career commitment and career success was found in several studies (Jones \& Whitmore, 1995; Day \& Allen, 2004; Poon, 2004). According to Kidd and Green's study (2006) career commitment and organizational commitment are some of the determinants of career success. Ballout's (2009) study showed that career commitment was predicted by subjective career success.

Hall (1971) asserted that career commitment is effected by the extent to which an individual feels herself/himself as competent and successful in her/his career. Aryee and Tan (1992) found that there is a significant influence of career satisfaction on career commitment. Aryee and Debrah (1993) concluded that career satisfaction has a significant direct effect on career commitment.

Carson, Roe, Birkenmeier and Philips's (1999) study elicited that individuals who have high career commitment have a higher career satisfaction than those who have lower career commitment. According to Goulet and Singh's (2001) study, the more satisfied employees are also more committed to their careers. Day and Allen's study (2004) showed that career commitment is positively related to career satisfaction. According to Poon's (2004) study, intrinsic job outcomes like subjective career success are influenced by career satisfaction, career mentoring, career commitment and perceptions of career success.

In a study of careers of women which conducted by Punnett et al. (2007) showed that career satisfaction is influenced by career success. Ballout's (2009) study revealed that, career commitment has a significant influence of career satisfaction through the moderation effect of self efficacy. According to the study of Jen-Ruei $\mathrm{Fu}$ (2010), career satisfaction is found as the most important determinant of participants' career commitment. Myrtle, Chen, Lui, and Fahey (2011) found that satisfaction with one's career has a direct impact on career commitment.

Thus, this study's hypothesis and the conceptual framework are presented below and in Figure 1., respectively.

H1: Career commitment is positively related to subjective career success.

$\mathrm{H} 2$ : Career commitment is positively related to career satisfaction.

H3: Career satisfaction significantly mediates the relationship between career commitment and subjective career success.

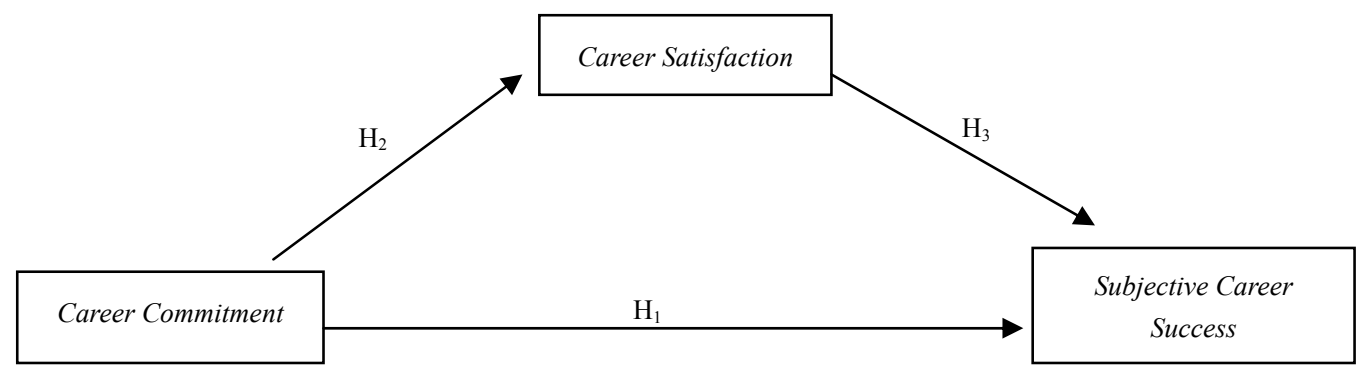

Figure 1. The Conceptual framework

\section{Method}

Career commitment scale is adopted from Blau's (1985) study. This scale consists of eight items on a five-point scale ( $1=$ strongly disagree, $5=$ =strongly agree). Some of the statements that it includes: "I spend a significant amount of personal time reading job-related journals or books'; "This is the ideal vocation for a life work". This scale has a coefficient alpha of 0.82 which is consistent with Nunnally's (1967) suggested reliability estimates of 0.70 (minimum) as the cut-off value.

Career satisfaction scale is adopted from Greenhaus et al. (1990) study. Career satisfaction is measured with five items on a five-point scale ( $1=$ strongly disagree, $5=$ strongly agree). Some of the statements they asked were "I'm satisfied with the progress I have made toward meeting my goals for advancement"; "I'm satisfied with the progress I have made toward meeting my overall career goals". This scale has a coefficient alpha of 0.88 which is consistent with Nunnally's (1967) suggested reliability estimates of 0.70 (minimum) as the cut-off value.

Subjective career success is adopted from Turban and Dougherty's (1994) study. This scale consists of four items ( $1=$ considerably below average, $5=$ considerably above average). This scale has a coefficient alpha of 0.81 which is consistent with Nunnally's (1967) suggested reliability estimates of 0.70 (minimum) as the cut-off 
value. Some of the questions they asked were "How successful do your 'significant others' feel your career has been?"; "Given your age, do you think that your career is on 'schedule', or or ahead or behind schedule?"

This study was conducted in the hazelnut processing industry in Giresun/Turkey. Giresun is one of the cities that placed in the Blacksea Region of Turkey. Giresun's hazelnut quality is the highest quality hazelnuts in the world (HPG). For this reason, hazelnut processing industry is a vital issue for Giresun's economy. According to the Chamber of Commerce and Industry of Giresun, over 150 hazelnut processing companies do business in Giresun. This study was conducted on employees who work in these companies.

During adaptation of the measures into Turkish, the method of Brislin, Lonner and Thorndike (1973) was used, which consisted of four steps: forward translation, assessment of forward translation, backward translation, and assessment of backward translation. All of the English versions of the questionnaires were translated into Turkish by the researcher and reviewed by a colleague who is native in both Turkish and English and an assistant professor of English to assure clarity of terminology.

Stevens (1995) asserts, an acceptable reliability using individual employee survey data can be achieved by having at least 15 respondents per organization. For achieving that target, Stevens (1995) suggests the distribution of a minimum of 24 questionnaires for each participating organization. In total, those 150 manufacturers' were contacted to participate to this study. A total of 25 companies agreed to participate (a response rate 16,66 per cent).

Participants were explained the purpose of the study and invited to fill out the survey. Four hundred surveys were distributed. Distributed surveys were collected after 5 days. From some companies only received five or four questionnaires which were excluded because of Stevens' target. Other organizations, fortunately, provided 15,16 or 17 completed surveys. As a result, the number of questionnaires that involved in this study is 351 . The response rate is $87,75 \%$. All of the participants were choosen from non-managerial positions. Approximately, $42 \%$ of the participants' were females. Demographic characteristics of employees weren't asked (except gender) to increase the participation to study.

\section{Results}

According to the reliability analysis, the cronbach's alpha value of career commitment scale is 0.786 . Subjective career success' and career satisfaction's cronbach's alpha values are 0.817 and 0.774 , respectively. For ensuring the uni-dimensionality of scales, career commitment (CC), career satisfaction (CS) and subjective career success (SCS), factor analysis were done and presented in Table 1.

Table 1. Results of factor analysis using principal component analysis

\begin{tabular}{lllll}
\hline Items & Communalities & Eigen Values & $\begin{array}{l}\text { Percentage } \\
\text { Explained }\end{array}$ & $\begin{array}{l}\text { Variance } \\
\begin{array}{l}\text { Cumulative } \\
\text { Variance Explained }\end{array}\end{array}$ \\
\hline CC1* ${ }^{*}$ & 0.527 & 3.856 & 48.200 & 48.200 \\
CC2 & 0.447 & 0.916 & 11.450 & 59.650 \\
CC3 & 0.546 & 0.677 & 8.460 & 68.110 \\
CC4 & 0.407 & 0.641 & 8.010 & 76.120 \\
CC5 & 0.403 & 0.556 & 6.950 & 83.070 \\
CC6 & 0.476 & 0.513 & 6.412 & 89.482 \\
CC7 & 0.459 & 5.573 & 95.055 \\
CC8 & 0.552 & 0.382 & 4.945 & 100.000 \\
SCS1 & 0.498 & 0.610 & 65.250 \\
SCS2 & 0.657 & 0.454 & 14.250 & 79.500 \\
SCS3 & 0.702 & 0.366 & 11.350 & 90.850 \\
SCS4 & 0.653 & 9.150 & 100.000 \\
CS1 & 0.598 & 2.747 & 54.940 & 54.940 \\
CS2 & 0.625 & 0.699 & 13.980 & 68.920 \\
CS3 & 0.495 & 0.657 & 13.140 & 82.060 \\
CS4 & 0.431 & 0.539 & 10.780 & 92.840 \\
CS5 & 0.589 & 0.358 & 7.160 & 100.000 \\
\hline
\end{tabular}

Note. "*”: Reverse coded items. 
For following the steps of Baron and Kenny's (1986) study, multiple regression analysis were done and presented in Table 2. After that, Sobel test was done to show the significance of mediation.

Regression with career commitment as an independent variable and career success as a dependent variable was resulted in significant association between the variables $(F=217.64, p<0.0001$, Std. $\beta=0.641)$. Regression with career commitment as an independent variable and career satisfaction as a dependent variable resulted in significant association between the variables $(F=193.47, p<0.0001$, Std $\beta=0.658)$. Regression with career satisfaction as an independent variable and subjective career success as a dependent variable resulted in significant association between the variables $(F=237.73, p<0.0001$, Std $\beta=0.694)$.

Multiple regression with career satisfaction and career commitment as independent variables and career success as the dependent variable resulted in significant association between among the variables $(F=164.62, p<$ 0.0001 , Std. $\beta=0.347$ for career satisfaction and Std. $\beta=0.421$ for career commitment). These are the steps that should be followed according to Baron and Kenny's study. The purpose is here to establish zero-order relationships among the variables that exist. If at least one of these relationships is non-significant, it can be said that mediation is not possible in this test.

Table 2. Results of Baron and Kenny's test

\begin{tabular}{lllll}
\hline Steps & Variables & Sig. & B & Adj. R2 \\
\hline 1 & CC \& CS & 0.000 & 0.497 & .423 \\
2 & CC \& SCS & 0.000 & 0.426 & .427 \\
3 & CS \& SCS & 0.000 & 0.594 & .506 \\
4 & CC and CS \& SCS & 0.000 & 0.227 & .571 \\
& & 0.000 & 0.385 & \\
\hline
\end{tabular}

According to results of Baron and Kenny's test (as shown in Table 2), steps from one to three, all of this study's hypothesis are supported. In the fourth step, it can be concluded that, career commitment is statistically significant implying partial mediation by career satisfaction.

Finally, the Sobel test was done for mediation effect of career satisfaction in this study. According to the test results, it can be concluded that the mediation effect of career satisfaction is statistically significant for all three models in this study (Sobel's z-statistics $>1.96$ ).

\section{Discussion}

Nowadays, organizations that want to sustain their compatitive advantage should be aware of the importance of 'careers' in their workforces. For retaining and motivating a competent and satisfied workforce, it is important to understand the factors which may affect the employees' subjective career success. Traditional career types have been disappearing and turning into protean careers. So, understanding and creating new approaches for career commitment is a vital mission for the organizations which want to survive and compete for a long time. Besides, researchers assert that career commitment is becoming an important management concept (Baruch, 1998; Poon, 2004).

According to the test results, career commitment was found to predict subjective career success in this study. In addition to that, the mediation effect of career satisfaction was tested. Test results showed that, career satisfaction mediated the positive effects of career commitment on subjective career success. These results are similar with the results of Srikanth and Israel's study (2012). This present study may guide organizations' human resource management departments for getting and understanding today's workforce's point of view on subjective career success from the perspective of career commitment and career satisfaction structure.

In this study, there are some limitations. One of them is, this study is a cross-sectional study and perhaps this cross-sectional data would not allow us to draw causal inferences concerning various hypothesised relations. The other limitation is, the assessment variables were self-reported in a one survey by combining three scales of this study, namely career commitment, career satisfaction and subjective career success. Because of that reason, common method bias could have inflated correlations between this study's variables. Since a common source bias exists in this study, a longitudinal and a cross-cultural study may provide a better understanding in future studies. Besides, researchers have used career satisfaction as a measure of subjective career success (Heslin, 2003; Ng, Eby, Sorensen, \& Feldman, 2005). A longitudinal research design may be used to bring to light the 
linkage between subjective career success and career satisfaction.

This study's sample is taken from hazelnut processing industry in Giresun; so for the future studies, the participants can be chosen from different territories, industries, status or even countries. Besides, other factors than career satisfaction (personality traits, work-life balance, etc.), as a mediator, can be included in the models. In the literature, since there is not any study that conducted in hazelnut processing industry in this study's context; so, this study makes a valuable contribution to the literature.

\section{References}

Arthur, M. B., Hall, D. T., \& Lawrence, B. S. (1989). Generating New Directions in Career Theory: The Case for a Transdisciplinary Approach. In Arthur, M. B., Hall, D. T., \& Lawrence, B. S. (Eds.), Handbook of Career Theory. Cambridge: Cambridge University Press.

Aryee, S., \& Tan, K. (1992). Antecedents and Outcomes of Career Commitment. Journal of Vocational Behavior, 39, 331-334. http://dx.doi.org/10.1016/0001-8791(92)90052-2

Aryee, S., \& Debrah, Y. A. (1993). A Cross Cultural Application of Career Planning Model. Journal of Organizational Behavior, 14, 119-127. http://dx.doi.org/10.1002/job.4030140203

Aryee, S., Yue, W. C., \& Chew, J. (1994). An Investigation of the Predictors and Outcomes of Career Commitment in Three Career Stages. Journal of Vocational Behavior, 44, 1-16. http://dx.doi.org/10.1006/jvbe.1994.1001

Ballout, H. I. (2009). Career Commitment and Career Success: Moderating Role of Self Efficacy. Career Development International, 14(7), 655-669. http://dx.doi.org/10.1108/13620430911005708

Barnett, B. R., \& Bradley, L. (2007). The Impact of Organizational Support for Career Development on Career Satisfaction. Career Development International, 12(7), 17-636. http://dx.doi.org/10.1108/13620430710834396

Baron, R., \& Kenny, D. (1986). The Moderator-Mediator Variable Distinction in Social Psychological Research: Conceptual, Strategic and Statistical Considerations. Journal of Personality and Social Psychology, 51(6), 1173-1182. http://dx.doi.org/10.1037/0022-3514.51.6.1173

Baruch, Y. (1998). The Rise and Fall of Organizational Commitment. Human Systems Management, 17(2), $135-143$.

Baruch, Y. (2004). Managing Careers: Theory and Practice. London: Prentice Hall.

Baruch, Y., \& Budhwar, P. (2006). A Comparative Study of Career Management Practices in Britain and India. International Business Review, 15(1), 84-101. http://dx.doi.org/10.1016/j.ibusrev.2005.11.001

Blau, G. L. (1985). Measurement and Prediction of Career Commitment. Journal of Occupational Psychology. 58(4), 277-288. http://dx.doi.org/10.1111/j.2044-8325.1985.tb00201.x

Blau, G. (1988). Further Exploring the Meaning and Measurement of Career Commitment. Journal of Vocational Behavior, 32, 284-297. http://dx.doi.org/10.1016/0001-8791(88)90020-6.

Breland, J. W., Treadway, D. C., Duke, A. B., \& Adams, G. L. (2007). The Interactive Effect of Leader-Member Exchange and Political Skill on Subjective Career Success. Journal of Leadership and Organizational Studies, 13(3), 1-14. http://dx.doi.org/10.1177/10717919070130030101

Bremner, B., Robello, K., Schiller, Z., \& Weber, J. (1991). The Age of Consolidation. Business Week, 86-94.

Carson, K. D., \& Bedeian, A. G. (1994). Career Commitment: Construction of a Measure and Examination of Its Psychometric Properties. Journal of Vocational Behavior, 44, 237-262. http://dx.doi.org/10.1006/jvbe.1994.1017

Carson, K. D., Carson, P. P., Roe, C. W., Birkenmeier, B. J., \& Philips, J. S. (1999). Four Commitment Profiles and Their Relationships to Empowerment, Service Recovery and Work Attitudes. Public Personnel Management, 28, 1-13.

Collarelli, S. M., \& Bishop, R. C. (1990). Career Commitment: Functions, Correlates, and Management. Group and Organization Studies, 15, 158-176. http://dx.doi.org/10.1177/105960119001500203

Day, R., \& Allen, T. (2004). The Relationship Between Career Motivation and Self-Efficacy with Protege Career Success. Journal of Vocational Behavior, 64, 72-91. http://dx.doi.org/10.1016/S0001-8791(03)00036-8

Erdogan, B., Kraimer, M. L., \& Liden, R. C. (2004). Work Value Congruence and Intrinsic Career Success: The 
Compensatory Roles of Leader-Member Exchange and Perceived Organizational Support. PersonnePsychology, 57, 305-332. http://dx.doi.org/10.1111/j.1744-6570.2004.tb02493.x

Gattiker, U. E., \& Larwood, L. (1986). Subjective Career Success: A Study of Managers and Support Personnel. Journal of Business and Psychology, 1, 78-94. http://dx.doi.org/10.1007/BF01018805

Gattiker, U. E., \& Larwood, L. (1988). Predictors for Managers' Career Mobility, Success, and Satisfaction. Human Relations, 41, 569-591. http://dx.doi.org/10.1177/001872678804100801

Goulet, L. R., \& Singh. P. (2001). Career Commitment: A Reexamination and an Extension. Journal of Vocational Behavior, 61, 73-91. http://dx.doi.org/10.1006/jvbe.2001.1844

Greenhaus, J. H. (1987). Career Management. New York: Dryden Press.

Greenhaus, J. H., Parasuraman, A., \& Wormley, W. M. (1990). Effects of Race on Organizational Experiences, Job Performance Evaluations, and Career Outcomes. Academy of Management Journal, 33(1), 64-86. http://dx.doi.org/10.2307/256352

Hall, D. T. (1971). A Theoretical Model of Career Subidentity Development in Organizational Settings. Organizational Behavior and Human Performance, 6, 50-76. http://dx.doi.org/10.1016/0030-5073(71)90005-5

Hall, D. T. (1976). Careers in organizations. Pacific Palisades, CA: Goodyear.

Hall, D. T. (2002). Careers in and out of organizations. CA: Sage, Thousand Oaks.

Hall, D. T., \& Mirvis, P. H. (1995). The New Career Contract: Developing The Whole Person at Midlife and Beyond. Journal of Vocational Behavior, 47, 269-289. http://dx.doi.org/10.1006/jvbe.1995.0004

Hall, D. T., \& Chandler, D. E. (2005). Psychological Success: When the Career is a Calling. Journal of Organizational Behavior, 26, 155-176. http://dx.doi.org/10.1002/job.301

Heslin, P. A. (2003). Self and Other-Referent Criteria of Career Success. Journal of Career Assessment, 11(3), 262-286. http://dx.doi.org/10.1177/1069072703254500

Heslin, P. A. (2005). Conceptualizing and Evaluating Career Success. Journal of Organizational Behavior, 26(2), 113-136. http://dx.doi.org/10.1002/job.270

HPG. (2013). Hazelnut Promotion Group. Retrieved from http://www.ftg.org.tr

Jen, R. F. (2010). Is Information Technology Career Unique? Exploring Differences in Career Commitment \& Its Determinants Among IT \& Non-IT Employees. International Journal of Electronic Business Management, 8(4), 263-271.

Judge, T. A., Cable, D. M., Bourdea, J. W., \& Bretz, R. D. Jr. (1995). An Empirical Investigation of the Predictors of Executive Career Success. Personnel Psychology, 48(3), 485-519. http://dx.doi.org/10.1111/j.1744-6570.1995.tb01767.x

Kidd, J. M., \& Green, F. (2006). The Careers of Research Scientists: Predictors of Three Dimensions of Career Commitment and Intention to Leave Science. Personnel Review, 35(3), 229-251. http://dx.doi.org/10.1108/00483480610656676

London, M., \& Stumpf, S. A. (1982). Managing Careers. MA: Addison-Wesiey.

Mirvis, H. P., \& Hall, D. T. (1994). Psychological Success and the Boundaryless Career. In Arthur, M. B. \& Rousseau, D. M. (Eds.), The Boundaryless Career. New York: Oxford University Press.

Mueller, C. W., Wallace, J. E., \& Price, J. L. (1992). Employee Commitment: Resolving Some Issues. Work and Occupations, 19(3), 211-236. http://dx.doi.org/10.1177/0730888492019003001

Myrtle, R. C., Chen, D. R., Lui, C., \& Fahey, D. (2011). Job and Career Influences on the Career Commitment of Health Care Executives. Journal of Health Organization and Management, 25(6), 693-710. http://dx.doi.org/10.1108/14777261111178565

Nabi, G. R. (1999). An Investigation into the Differential Profile of Predictors of Objective and Subjective Career Success. Career Development International, 4(4), 212-224. http://dx.doi.org/10.1108/13620439910270599

Ng, T. W. H., Eby, L. T., Sorensen, K. L., \& Feldman, D. C. (2005). Predictors of Objective and Subjective Career Success: a Meta-Analysis. Personnel Psychology, 58(2), 367-408. http://dx.doi.org/10.1111/j.1744-6570.2005.00515.x 
Noordin, F., Williams, T., \& Zimmer, C. (2002). Career Commitment in Collectivist and Individualist Cultures: A Comparative Study. International Journal of Human Resource Management, 13(1), 35-54. http://doi.dx.org/10.1080/09585190110092785

Nunnally, J. C. (1970). Introduction to Psychological Measurement. New York: McGraw-Hill.

Nussbaum, B. (1991). I'm worried about my job! Business Week, 7, 94-97.

Poon, J. M. L. (2004). Career Commitment and Career Success: Moderating Role of Emotion Perception. Career Development International, 9(4), 374-390. http://dx.doi.org/10.1108/13620430410544337

Punnett et al. (2007). Career Success and Satisfaction: a Comparative Study in Nine Countries. Women in Management Review, 22(5), 371-390. http://dx.doi.org/10.1108/09649420710761446

Randall, D. M. (1987). Commitment and the Organization: The Organization Man Revisited. Academy of Management Review, 12, 460-471. http://dx.doi.org/10.5465/AMR.1987.4306561

Seibert, S. E., \& Kraimer, M. L. (2001). The Five-Factor Model of Personality and Career Success. Journal of Vocational Behavior, 58(1), 1-21. http://dx.doi.org/10.1006/jvbe.2000.1757

Seibert, S. E., Kraimer, M. L., \& Liden, R. C. (2001). A Social Capital Theory of Career Success. Academy of Management Journal, 44(2), 219-237. http://dx.doi.org/10.2307/3069452

Srikanth, P. B., \& Israel, D. (2012). Career Commitment\&Career Success: Mediating Role of Career Satisfaction. Indian Journal of Industrial Relations, 48(1).

Stevens, J. (1995). Applied Multivariate Statistics for the Social Sciences. Mahwah, NY: Lawrence Erlbaum.

Turban, D. B., \& Dougherty, T. W. (1994). Role of Protégé Personality in Receipt of Mentoring and Career Success. Academy of Management Journal, 37(3), 688-702. http://dx.doi.org/10.2307/256706

\section{Copyrights}

Copyright for this article is retained by the author(s), with first publication rights granted to the journal.

This is an open-access article distributed under the terms and conditions of the Creative Commons Attribution license (http://creativecommons.org/licenses/by/3.0/). 